\title{
SISTEM PENDUKUNG KEPUTUSAN PEMILIHAN BALITA SEHAT SE-KECAMATAN SEI LEPAN MENGGUNAKAN METODE MULTI ATRIBUTTE UTILITY THEORY (MAUT) (STUDI KASUS: PUSKESMAS DESA LAMA)
}

\author{
Septia Fajarika \\ Program Studi Teknologi Informatika STMIK Budi Darma,Medan, Indonesia \\ Email:Septiafajarika688@gmail.com
}

\begin{abstract}
Abstrak
Semua harapan orang tua menginginkan seorang balita yang sehat, tetapi tidak semua orang tua khususnya ibu mengerti tentang kesehatan balita, cara merawat balita, asupan gizi atau takaran gizi untuk balita tidak semua orang tua khususnya ibu mengerti akan hal itu, sehingga hal tersebut menyebabkan balita tidak mendapatkan kesehatan yang baik dan takaran gizi yang cukup dari para ibu. Untuk mengatasi permasalahan diatas, maka pihak Puskesmas Desa Lama membuat program pemilihan balita sehat sekecamatan Sei Lepan guna untuk membantu para ibu agar lebih memahami tentang kesehatan balita, tentang asupan gizi balita dan juga agar pihak Puskesmas Desa Lama mengetahui seberapa banyak balita sehat yang ada di Kecamatan Sei Lepan, namun pemilihan tersebut masih bersifat manual yang membutuhkan waktu yang sangat lama.Agar tidak terjadi masalah di atas, maka perlu dibangun aplikasi Sistem Pendukung Keputusan Pemilihan Balita Sehat Kecamatan Sei Lepan dengan menggunakan metode Multi Attribute Utility Theory (MAUT), sehingga dapat membantu pihak Puskesmas Desa Lama dalam proses penilaian agar lebih akurat dan keputusan yang ditetapkan hasilnya memuaskan.
\end{abstract}

Kata Kunci: Sistem Pendukung Keputusan, Pemilihan Balita Sehat, Metode MAUT.

\begin{abstract}
All hopes parents want a healthy toddler, but not all parents, especially mothers, understand about toddler health, how to care for toddlers, nutritional intake or nutritional quantities for toddlers, not all parents, especially mothers, understand that, so this causes toddlers to not get good health and an adequate dose of nutrition from mothers.To overcome the above problems, the Old Village Health Center made a selection program for healthy toddlers from Sei Lepan sub-district in order to help mothers understand more about toddler health, about the nutrition intake of toddlers and also so that the Old Village Health Center knows how many healthy toddlers there are in the District Sei Lepan, but the selection is still manual which requires a very long time.In order to avoid the above problems, it is necessary to build an application for a Healthy Toddler Selection Decision Support System in Sei Lepan District by using the Multi Attribute Utility Theory (MAUT) method, so that it can help the Old Village Health Center in the assessment process to make it more accurate and the decisions made are satisfactory.
\end{abstract}

Keywords: Decision Support System, Healthy Toddler Selection, MAUT Method.

\section{PENDAhUluan}

Untuk bisa menjadi balita sehat asupan gizi makanan adalah kunci utamanya. Makanan balita harus mencakupi zat gizi seimbang, yaitu energi, karbohidrat, protein, lemak, vitamin, mineral, air, dan serat. Zat gizi simbang membantu proses pertumbuhan dan perkembangan anak. Balita membutuhkan energi dalam jumlah besar, namun sekitar 10-20\% harus berasal dari protein berfungsi sebagai zat pembangun, karna itu, diperlukan perhitungan tepat kebutuhan energi dan protein pada balita[8]. Besar kebutuhan energi dan protein balita didasarkan pada berat badan dan prosentase kebuthan energi dan protein. Syarat dari menu seimbang adalah memenuhi kecukupan energi tubuh, kebutuhan protein untuk perkembangan, perbaikan sel yang rusak serta pemeliharannya. Menu juga harus mengandung cukup lemak yang berfungsi memnuhi kebutuhan asam lemak esensial.

Puskesmas Desa Lama merupakan pusat layanan kesehatan masyarakat untuk pertolongan pertama bagi masyarakat daerah setempat yang ingin berobat atau berkonsultasi tentang kesehatan mereka, yang melayani semua masalah kesehatan masyarakat baik dibidang persalinan, pengobatan, rawat berjalan, posyandu bayi dan balita dan lain sebagainya. Di Puskesmas Desa Lama mempunyai beberapa pegawai yang akan melayani masalah kesehatan masyarakat sesuai tugasnya, agar masyarakat terlayani dengan baik. Salah satu tugas pegawai yaitu untuk memastikan semua balita sehat.

Berdasarkan penelitian terdahulu yang dilakukan oleh Ratih Kumala Sari dan Hamdani yang berjudul "Sistem Pendukung Keputusan Pemilihan Balita Sehat Menggunakan Penalaran Fuzzy Tsukamoto (Studi Kasus : Puskesmas Wonorejo Samarinda)" menyimpulkan bahwa penelitian menghasilkan aplikasi berbasis sistem pendukung keputusan yang dapat digunakan sebagai bahan pertimbangan oleh pengguna untuk membentu proses pengambilan keputusan saat akan memilih balita sehat di Puskesmas Wonorejo Samarinda, sehingga dapat menjadi penentuan peringkat yang dihasilkan dari pengurutan nilai tegas (crips) dari nilai yang besar ke nilai yang kecil tidak efektif ketika ditemukan nilai yang sama[1]. 


\section{TEORITIS}

\subsection{Sistem Pendukung Keputusan}

Sistem merupakan kumpulan sub-sub sistem (elemen) yang saling berkorelasi satu dengan yang lainnya untuk mencapai tujuan tertentu. Sebagai contoh yaitu sebuah perusahaan memiliki sistem manajerial yang terdiri dari bottom management, middle management dan top management yang memiliki tujuan untuk mencapai kemajuan masyarakat. Sistem Pendukung Keputusan dapat diartikan sebagai suatu sistem yang dirancang yang digunakan untuk mendukung manajemen dalam pengambilan keputusan [5].

\subsection{Pemilihan Balita Sehat}

Besar kebutuhan energi dan protein balita didasarkan pada berat badan dan prosentase kebuthan energi dan protein. Syarat dari menu seimbang adalah memenuhi kecukupan energi tubuh, kebutuhan protein untuk perkembangan, perbaikan sel yang rusak serta pemeliharannya.Balita membutuhkan energi dalam jumlah besar, namun sekitar 10-20\% harus berasal dari protein berfungsi sebagai zat pembangun, karna itu, diperlukan perhitungan tepat kebutuhan energi dan protein pada balita[8].

\subsection{Metode Multi Atributte Utility Theory (MAUT)}

Metode Multi-Attribute Utility Theory (MAUT) adalah "suatu metode perbandingan kuantitatif yang biasanya mengkombinasikan pengukuran atas biaya resiko dan keuntungan yang berbeda. Setiap kriteria yang ada memiliki beberapa alternatif yang mampu memberikan solusi, Untuk mencari alternatif yang mendekati dengan keinginan user maka untuk mengidentifikasikannya dilakukan perkalian terhadap skala prioritas yang sudah ditentukan[9].

Dimana Vi(x) merupakan nilai evaluasi dari sebuah objek ke i dan wi merupakan bobot yang menentukan nilai dari seberapa penting elemen ke i terhadap elemen lainnya. Sedangkan $\mathrm{n}$ merupakan jumlah elemen. Total dari bobot adalah 1. Secara ringkas langkah-langkah dalam metode MAUT adalah sebagai berikut[10]:

1. Pecah sebuah keputusan ke dalam dimensi yang berbeda.

2. Tentukan bobot alternatif pada masing-masing dimensi.

3. Daftar semua alternatif

4. Masukkan utility untuk masing-masing alternatif sesuai atributnya.

5. Kalikan utility dengan bobot untuk menentukan nilai masing-masing alternatif.

Normalisasi matrik:

Ket:

$$
(x)=\frac{X-X i}{X i+-X i-}
$$

$\mathrm{U}(\mathrm{x})=$ Normalisasi bobot alternatif $\mathrm{x}$

$\mathrm{X}=$ Bobot alternatif

$\mathrm{Xi}-{ }^{-}$Bobot terbaik $(\min )$ dari kriteria ke $\mathrm{x}$

$\mathrm{Xi}+=$ Bobot terbaik $(\max )$ dari kriteria ke $\mathrm{x}$

$$
\mathrm{V}(x)=\sum_{i=1}^{n} \text { wj. xij }
$$

Dimana $\operatorname{Vi}(\mathrm{x})$ merupakan nilai evaluasi dari sebuah objek ke i dan wi merupakan bobot yang menentukan nilai dari seberapa penting elemen ke i terhadap elemen lainnya. Sedangkan $n$ merupakan jumlah elemen.

\section{ANALISA DAN PEMBAHASAN}

Dalam proses pemilihan balita sehat se-kecamatan sei lepan maka perlu membangun aplikasi sistem pendukung keputusan, yang merupakan sebuah sistem yang dapat memberikan kemampuan pemecahan terhadap masalah dalam berbasis komputer agar dapat membantu pihak Puskesmas dalam pengambilan keputusan dalam pemilihan balita sehat Kecamatan Sei Lepan dengan menerapkan metode Multi Attribute Utility Theory (MAUT). Sehingga Sistem Pendukung Keputusan dapat mengetahui dan membandingkan balita mana yang layak dikatakan balita sehat, yang dapat membantu dan memperumdah pihak Puskesmas Desa Lama dalam melakukan penilian dan pemilihan dalam memilih balita sehat Kecamatan Sei Lepan pada Puskesmas Desa Lama dan keputusan yang ditetapkan oleh pihak Puskesmas Desa Lama hasilnya akurat dan memuaskan para orang tua.

\subsection{Data Alternatif}

Selanjutnya yang dijadikan alternatif atau sampel dalam pemilihan balita sehat Kecamatan Sei Lepan yaitu 10 (sepuluh) balita yang ada di Kecamatan Sei Lepan yang masing-masing balita mewakili setiap desa yang ada di Kecamatan Sei Lepan. 
Tabel 1. Alternatif

\begin{tabular}{llll}
\hline Kode & Alternatif & L/P & Asal Desa \\
\hline A1 & Alam & L & Puraka 1 \\
A2 & Mirza & P & Jasa Makmur \\
A3 & Alza Kirana & P & Desa Lama \\
A4 & M. Satya & L & Desa Makmur \\
A5 & Tiara & P & Alur II \\
A6 & Fahri & L & Puraka II \\
A7 & Pikri Arpiansyah & L & Pakis \\
A8 & Aulia Zahra & P & Alba Baru \\
A9 & Tasya & P & Paya Juluk \\
A10 & Herpiza & L & Aras Mesin \\
\hline
\end{tabular}

\subsection{Menentukan Kriteria dan Bobot}

Dalam pemilihan balita sehat Kecamatan Sei Lepan menggunakan metode Multi Attribute Utility Theory (MAUT) maka diperlukan kriteria-kriteria dan bobot untuk menyelesaikan proses perhitungan sehingga akan mendapatkan alternatif terbaik.

Tabel 2. Bobot Kriteria

\begin{tabular}{ll}
\hline \multicolumn{1}{c}{ Kriteria } & Nilai \\
\hline Gigi dan Mulut (C1) & $10 \%$ \\
Rambut (C2) & $10 \%$ \\
Jari Tangan dan Kuku (3) & $10 \%$ \\
Kulit (C4) & $20 \%$ \\
Pendengaran (C5) & $10 \%$ \\
Penglihatan (C6) & $10 \%$ \\
Pernafasan (C7) & $10 \%$ \\
Anggota Gerak(8) & $20 \%$ \\
Hasil & $100 \%$ \\
\hline
\end{tabular}

Berdasarkan dari masing-masing kriteria di atas maka akan diterapkan nilai bobotnya menggunakan grafik fuzzy. Adapaun bobot dari kriteria terdiri dari 4 yaitu: Sangat buruk (SBR), buruk (BR), cukup(C), baik(B), sangat baik (SB).

Keterangan:

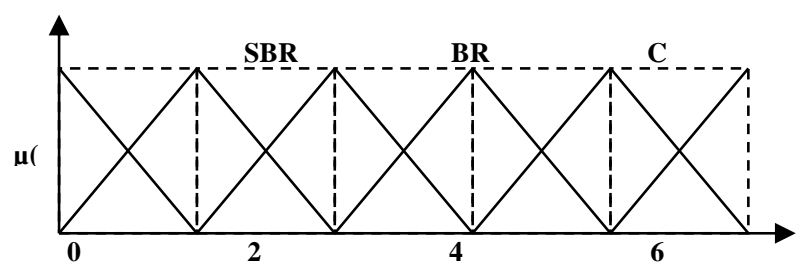

$$
\begin{array}{ll}
\text { SBR } & =\text { Sangat Buruk } \\
\text { BR } & =\text { Buruk } \\
\text { C } & =\text { cukup } \\
\text { B } & =\text { Baik } \\
\text { SB } & =\text { Sangat Baik }
\end{array}
$$

Dari gambar grafik diatas bilangan fuzzy dapat dikonversikan menjadi bobot. Untuk lebih jelas data bobot (w) ditentukan pada tabel berikut.

Tabel 3. Pemberian nilai bilangan fuzzy dan Bobot

\begin{tabular}{cc}
\hline Bilangan fuzzy & Nilai \\
\hline Sangat Buruk & 2 \\
Buruk & 4 \\
Cukup & 6 \\
Baik & 8 \\
Sangat Baik & 10 \\
\hline
\end{tabular}

Tabel 4. Kriteria Gigi dan Mulut 


\begin{tabular}{ccc}
\hline Gigi dan Mulut (C1) & Bilangan Fuzzy & Nilai \\
\hline A1 & Sangat Baik & 10 \\
A2 & Cukup & 6 \\
A3 & Sangat Baik & 10 \\
A4 & Buruk & 4 \\
A5 & Sangat Baik & 10 \\
A6 & Buruk & 4 \\
A7 & Buruk & 4 \\
A8 & Cukup & 6 \\
A9 & Buruk & 4 \\
A10 & Cukup & 6 \\
\hline
\end{tabular}

Tabel 5. Kriteria Rambut

\begin{tabular}{ccc}
\hline Rambut $(\mathrm{C} 2)$ & Bilangi Fuzzy & Nilai \\
\hline A1 & Sangat Baik & 10 \\
A2 & Cukup & 6 \\
A3 & Cukup & 6 \\
A4 & Sangat Buruk & 2 \\
A5 & Cukup & 6 \\
A6 & Sangat Baik & 10 \\
A7 & Cukup & 6 \\
A8 & Sangat Baik & 10 \\
A9 & Cukup & 6 \\
A10 & Cukup & 6 \\
\hline
\end{tabular}

Tabel 6. Kriteria Jari Tangan dan Kuku

\begin{tabular}{|c|c|c|}
\hline Jari Tangan dan Kuku (C3) & Bilangan fuzzy & Nilai \\
\hline $\mathrm{A} 1$ & Cukup & 6 \\
\hline A2 & Cukup & 6 \\
\hline A3 & Sangat Baik & 10 \\
\hline A4 & Cukup & 6 \\
\hline A5 & Cukup & 6 \\
\hline A6 & Cukup & 6 \\
\hline A7 & Sangat Baik & 10 \\
\hline A8 & Cukup & 6 \\
\hline A9 & Cukup & 6 \\
\hline A10 & Cukup & 6 \\
\hline \multicolumn{3}{|c|}{ Tabel 7. Kriteria Kulit } \\
\hline Kulit (C4) & Bilangan Fuzzy & Nilai \\
\hline A1 & Sangat Baik & 10 \\
\hline $\mathrm{A} 2$ & Buruk & 4 \\
\hline A3 & Buruk & 4 \\
\hline A4 & Sangat Baik & 10 \\
\hline A5 & Sangat Baik & 10 \\
\hline A6 & Buruk & 4 \\
\hline A7 & Buruk & 4 \\
\hline A8 & Buruk & 4 \\
\hline A9 & Buruk & 4 \\
\hline A10 & Sangat Baik & 10 \\
\hline \multicolumn{3}{|c|}{ Tabel 8. Kriteria Pendengaran } \\
\hline Pendengaran (C5) & Bilangan fuzzy & Nilai \\
\hline $\mathrm{A} 1$ & Cukup & 6 \\
\hline A2 & Cukup & 6 \\
\hline A3 & Sangat Baik & 10 \\
\hline
\end{tabular}




\begin{tabular}{ccc}
\hline A4 & Sangat Baik & 10 \\
A5 & Sangat Baik & 10 \\
A6 & Cukup & 6 \\
A7 & Cukup & 6 \\
A8 & Cukup & 6 \\
A9 & Cukup & 6 \\
A10 & Sangat Baik & 10 \\
\hline \multicolumn{3}{|}{ Tabel 9. Kriteria Penglihatan } \\
\hline Penglihatan (C6) & Bilangan Fuzzy & Nilai \\
\hline A1 & Sangat Baik & 10 \\
A2 & Sangat Baik & 10 \\
A3 & Sangat Baik & 10 \\
A4 & Sangat Baik & 10 \\
A6 & Sangat Baik & 10 \\
A7 & Baik & 8 \\
A8 & Sangat Baik & 10 \\
A9 & Sangat Buruk & 2 \\
A10 & Baik & 8 \\
\end{tabular}

Tabel 10. Kriteria Pernafasan

\begin{tabular}{ccc}
\hline Pernafasan $($ C7) & Bilangan Fuzzy & Nilai \\
\hline A1 & Buruk & 4 \\
A2 & Sangat Baik & 10 \\
A3 & Buruk & 4 \\
A4 & Buruk & 4 \\
A5 & Buruk & 4 \\
A6 & Buruk & 4 \\
A7 & Buruk & 4 \\
A8 & Buruk & 4 \\
A9 & Buruk & 4 \\
A10 & Buruk & 4 \\
\hline
\end{tabular}

Tabel 11. Kriteria Anggota Gerak

\begin{tabular}{ccc}
\hline Anggota Gerak (C8) & Bilangan fuzzy & Nilai \\
\hline A1 & Cukup & 6 \\
A2 & Cukup & 6 \\
A3 & Cukup & 6 \\
A4 & Sangat Baik & 10 \\
A5 & Cukup & 6 \\
A6 & Cukup & 6 \\
A7 & Cukup & 6 \\
A8 & Cukup & 6 \\
A9 & Cukup & 6 \\
A10 & Sangat Baik & 10 \\
\hline
\end{tabular}

Tabel 12. Rating Kecocokkan Alternatif dan Kriteria

\begin{tabular}{ccccccccc}
\hline & C1 & C2 & C3 & C4 & C5 & C6 & C7 & C8 \\
\hline A1 & 10 & 10 & 6 & 10 & 6 & 10 & 4 & 6 \\
A2 & 6 & 6 & 6 & 4 & 6 & 10 & 10 & 6 \\
A3 & 10 & 6 & 10 & 4 & 10 & 10 & 4 & 6 \\
A4 & 4 & 2 & 6 & 10 & 10 & 10 & 4 & 10 \\
A5 & 10 & 6 & 6 & 10 & 10 & 10 & 4 & 6 \\
A6 & 4 & 10 & 6 & 4 & 6 & 8 & 4 & 6 \\
A7 & 4 & 6 & 10 & 4 & 6 & 10 & 4 & 6 \\
\hline
\end{tabular}




\begin{tabular}{ccccccccc}
\hline A8 & 6 & 10 & 6 & 4 & 6 & 2 & 4 & 6 \\
A9 & 4 & 6 & 6 & 4 & 6 & 8 & 4 & 6 \\
A10 & 6 & 6 & 6 & 10 & 6 & 10 & 4 & 10 \\
\hline
\end{tabular}

Matriks Keputusan

$$
\left[\begin{array}{cccccccc}
10 & 10 & 6 & 10 & 6 & 10 & 4 & 6 \\
6 & 6 & 6 & 4 & 6 & 10 & 10 & 6 \\
10 & 6 & 10 & 4 & 10 & 10 & 4 & 6 \\
4 & 2 & 6 & 10 & 10 & 10 & 4 & 10 \\
10 & 6 & 6 & 10 & 10 & 10 & 4 & 6 \\
4 & 10 & 6 & 4 & 6 & 8 & 4 & 6 \\
4 & 6 & 10 & 4 & 6 & 10 & 4 & 6 \\
6 & 10 & 6 & 4 & 6 & 2 & 4 & 6 \\
4 & 6 & 6 & 4 & 6 & 8 & 4 & 6 \\
6 & 6 & 6 & 10 & 6 & 10 & 4 & 10
\end{array}\right]
$$

Normalisasi Matriks

$\mathrm{A} 11=\frac{10-4}{10-4}=1$

$\mathrm{A} 12=\frac{10-2}{10-2}=1$

Dari perhitungan diatas dapat diperoleh Matriks Keputusan yang telah diternormalisasikan sebagai berikut:

\begin{tabular}{ccccccccc}
\hline Alternatif & C1 & C2 & C3 & C4 & C5 & C6 & C7 & C8 \\
A1 & 1 & 1 & 0 & 1 & 0 & 1 & 0 & 0 \\
A2 & 0,33 & 0,5 & 0 & 0 & 0 & 1 & 1 & 0 \\
A3 & 1 & 0,5 & 1 & 0 & 1 & 1 & 0 & 0 \\
A4 & 0 & 0 & 0 & 1 & 1 & 1 & 0 & 1 \\
A5 & 1 & 0,5 & 0 & 1 & 1 & 1 & 0 & 0 \\
A6 & 0 & 1 & 0 & 0 & 0 & 1,5 & 0 & 0 \\
A7 & 0 & 0,5 & 0 & 0 & 0 & 1 & 0 & 0 \\
A8 & 0,33 & 1 & 0 & 0 & 0 & 0 & 0 & 0 \\
A9 & 0 & 0,5 & 0 & 0 & 0 & 0,75 & 0 & 0 \\
A10 & 0,33 & 0,5 & 0 & 1 & 0 & 1 & 0 & 1 \\
Bobot & $10 \%$ & $10 \%$ & $10 \%$ & $20 \%$ & $10 \%$ & $10 \%$ & $10 \%$ & $20 \%$ \\
\hline
\end{tabular}

Tahap selanjutnya akan dilakukan perkalian matriks normalisasi dengan bobot preferensi:

A1 $=(10 * 1)+(10 * 1)+(10 * 0)+(20 * 1)+(10 * 0)+(10 * 1)+(10 * 0)+(20 * 0)=50$

$\mathrm{A} 10=(10 * 0,33)+(10 * 0,5)+(10 * 0)+(20 * 1)+(10 * 0)+(10 * 1)+(10 * 0)+(20 * 1)=58,3$

Tabel 13. Hasil Perkalian Matriks Ternormalisasi Dengan Bobot Preferensi

\begin{tabular}{llll}
\hline Kode & Alternatif & Hasil & Rank \\
\hline A1 & Alam & 50 & 4 \\
A2 & Mirza & 38,3 & 6 \\
A3 & Alza Kirana & 45 & 5 \\
A4 & M.Satya & 60 & 1 \\
A5 & Tiara & 55 & 3 \\
A6 & Fahri & 25 & 7 \\
A7 & Pikri Arpiansyah & 15 & 8 \\
A8 & Aulia Zahra & 13,3 & 9 \\
A9 & Tasya & 12,5 & 10 \\
A10 & Herpiza & 58,3 & 2 \\
\hline
\end{tabular}

Dari perhitungan diatas maka dapat hasil balita tersehat se-Kecamatan Sei Lepan. Adapaun hasil terakhir ranking tertinggi sebagai berikut:

Tabel 14. Hasil Perangkingan

Alternatif Rank




\begin{tabular}{ll} 
M.Satya & 1 \\
Herpiza & 2 \\
Tiara & 3 \\
Alam & 4 \\
Alza Kirana & 5 \\
Mirza & 6 \\
Fahri & 7 \\
Pikri Arpiansyah & 8 \\
Aulia Zahra & 9 \\
Tasya & 10 \\
\hline
\end{tabular}

\section{KESIMPULAN}

Berdasarkan dari analisa yang penulis lakukan pada bab-bab sebelumnya dapat diambil beberapa kesimpulan yaitu sebagai berikut:

1. Dalam pemilihan balita sehat kriteria-kriteria yang digunakan dalam penelitian ditentukan oleh pihak Puskesmas yang menurut peneliti sudah efektif untuk diimplementasikan.

2. Metode Multi Attribute Utility Theory (MAUT) sangat efektif dan akurat dalam mengimplementasikan pemilihan balita sehat karna memiliki beberapa langkah dan semua langkah dapat diselesaikan dengan baik.

3. Perancangan dalam pemilihan balita sehat se-Kecamatan menggunakan Microsoft Visual Studio 2008 dan database Mysql yang terdiri dari 5 form yaitu form login, form utama, form input alternatif, form input kriteria dan form keputusan.

\section{REFERENCES}

[1] Ratih Kumala Sari, "Sistem Pendukung Keputusan Pemilihan Balita Sehat Menggunakan Penalaran Fuzzy Tsukamoto.'

[2] R. Ramadiani, "Sistem Pendukung keputusan pemilihan tenaga kesehatan teladan menggunakan metode Multi-Attribute Utility Theory," vol. 3357, no. 1, pp. 1-12, 2019.

[3] M. K. Dicky novriansyah S.Kom, Konsep data mining vs sistem pendukung keputusan, Yogyakarta. Cv Budi Utama, 2014.

[4] said hi abbas lita asyriati latif, mohammad jamil, Sisten pendukung keputusan teori dan implementasi. Yogyakarta: Grub penerbit Cv Budi Utama, 2018.

[5] M. M. S. Nazarina, Menu Sehat Dan Aman Untuk Bayi. Jakarta Selatan: Pt Mizan Publika, 2008.

[6] N. Hadinata, "Implementasi Metode Multi Attribute Utility Theory (MAUT) Pada sistem pendukung keputusan dalam menentukan penerima kredit," vol. 07, Nomor, 2018.

[7] R. A. S. M. Shalahuddin, Rekayasa Perangkat Lunak. Bandung: Informatika, 2011.

[8] W. S. H. M.si, Membuat aplikasi berbasis pendekatan sistem dengan visual basic.net 2008. Jakarta: Pt Eleks media komputindo, 2008.

[9] A. St, Panduan menguasai PHP dan MySQL secara otodidak. Jakarta Selatan: Media Kita, 2010.

[10] M. A. J. Alam, MySQL Server Versi 5 dan Aplikasinya dalam Visual Basic 6 dan Delphi. Jakarta: Pt Eleks media komputindo, 2005.

[11] D. A. S. Kusumo, Pemrograman Visual Basic 2005. Jakarta: Pt Eleks media komputindo, 2005 